\title{
IAMJ
}

INTERNATIONAL

AYURVEDIC

MEDICAL JOURNAL

\section{A COMPARATIVE CLINICAL STUDY TO EVALUATE DIFFERENT SCHEDULES OF MARSHA NASYA WITH PRASARINI TAILA IN CERVICAL SPONDYLOSIS}

\author{
Krishnapriya A. $\mathrm{S}^{1}$, Praveen B. $\mathrm{S}^{2}$ \\ ${ }^{1}$ PG Scholar, ${ }^{2}$ Professor \& Head, \\ Post Graduate Dept of Pancakarma, Alva's Ayurveda Medical College, Moodbidri. Karnataka, India
}

Corresponding Author: as.krishnapriya27@gmail.com

\section{https://doi.org/10.46607/iamj1208082020}

(Published online: August 2020)

Open Access

(C) International Ayurvedic Medical Journal, India 2020

Article Received: 27/07/2020 - Peer Reviewed: 05/08/2020 - Accepted for Publication: 09/08/2020

(A) Check for updates

\begin{abstract}
Cervical spondylosis is one of the degenerative conditions of the cervical spine. It is commonly seen in old age, but nowadays it is nearly ubiquitous in young and middle-aged people. The symptoms consist of paraesthesia and pain in the distribution of fifth to eighth cervical dermatomes, pain being felt most frequently over the shoulder, arm, scapular region, forearm and hands. In young subjects, bony outgrowth may not be evident, but loss of the cervical curvature caused by spasm of neck muscles can be taken as a suggestive sign. The presentations of signs and symptoms of both diseases have close resemblance, so Vishvachi can be correlated with Cervical Spondylosis. Improper sitting postures and continuous work create pressure and stress that cause injury to spine, which may play an important role in producing this condition. NasyaKarma is considered as prime line of treatment in Urdhwa Jjathrugata Vikaras and could be effective, economical as well as affordable treatment modality. Prasarini Taila is indicated in all Vata Vikaras especially in Vishvachi. Keeping these points in mind, a comparative clinical study of different schedules of Marsha Nasya with Prasarini Taila in the management of Cervical Spondylosis is taken.
\end{abstract}

Keywords: Cervical Spondylosis, Vishvachi, Marsha Nasya, Nasyakarma, PrasariniTaila. 


\section{INTRODUCTION}

Cervical spondylosis occurs due to the degenerative condition of vertebral column with advancing age. It is characterized by pain and stiffness in the nape of neck may also be associated with radiating pain to either hand. Vishvachi is one among the Vatavyadhi characterized by pain extending from Talapratyanguli to Bahuprishta and produce symptoms such as Shoola and Karmakshaya of Bahu. Along with these symptoms it will also produces Ruk, Thoda and Stambha The signs and symptoms of cervical spondylosis resembles to Vishvachi. By foregoing cervical spondylosis may be correlated to Vishvachi. Being a Shoolapradhana Nanatmajavyadhi, it deprives the patient's ability to perform movements of upper limb, which inturn makes them unable to carry routine work. Nasyakarma being one of the prime treatment modalities in treating Vatavyadhi may be considered in the management of Visvhachi too. Nasya helps in developing strength of Urdhwajathru, Greeva and Bahu. PrasaraniTaila consist of Prasaranikwatha, Mastu, Amlakanjika, Ksheera, Citraka, Pippalimula, Yasti, Saindhavalavana, Vaca, Satapushpa, Devadaru, Rasna, Gajapippali, Jatamamsi, Raktachandana, Eranda, Bala, and Sunthi. The ingredients of Taila have Vatahara property. Moreover, this has indicated in Vishvachi. Various schedules are practiced in administration of Nasya but routinely Nasya is performed for consecutive seven days. In Vata dominant diseases it can be performed in alternative days also. So, this study is intended to find the effect of Prasarani Taila Nasyakarma in alternative seven days in comparison with Prasarani Taila Nasyakarma in consecutive seven days in the management of Vishvachi.

\section{Materials and Methods}

\section{Source of Data:-}

i. Drug Source: - From the source of procurement.

ii. Drug Preparation: - Dept of Rasashastra and Bhaishajya Kalpana, Alva's Ayurveda Medical College, Moodbidri.

iii. Sample Source: - OPD and IPD of PG studies of Pancakarma, Alva's Ayurveda Medical College Hospital, Moodbidri.

\section{Method of Data Collection: -}

a) Sample Size:- 40 patients suffering from Cervical Spondylosis and Vishvachi fulfilling the diagnostic and inclusion criteria belonging to either sex were selected for the clinical study. They were assigned into two equal groups comprising 20 each.

Study Design: - Comparative clinical study.

Selection Criteria: -The cases are selected as per Signs and Symptoms of Cervical Spondylosis.

b) Diagnostic Criteria:- The patients were diagnosed based on the following clinical signs and symptoms:-

- Neck pain

- Sensory loss in upper limbs

- Tenderness in cervical region

- Restricted movement of neck

- Pratyatma lakshana of Vishvachi

c) Inclusion Criteria :-

- Patients fulfilling the diagnostic criteria.

- Patients of the age group 20-60 years of either sex.

- Patients who are fit for Nasyakarma.

d) Exclusion Criteria :-

- Congenital conditions of cervical spine.

- Traumatic injury of the cervical spine.

- Patients with other medications are excluded.

Procedure

1) Poorvakarma - Abhyanga for face and neck with Moorchita Tila Taila. Pata Sveda did for face and neck.

2) Pradhanakarma - Patient is made to lie in supine position and the head maintained pralambitha position. Patient's eyes were covered with cotton pad. Nostril of the patient widened with left hand of physician. Then, $4 \mathrm{ml}$ of lukewarm Prasarini Taila is taken in Nasya Pranadi and 8 bindu instilled into each nostril.

3) Pascatkarma - After administration of Nasya, patient is advised to lie on supine position for about 2 minutes. Then the region of the ears, forehead, skin of scalp, cheeks, nape of neck, shoulder, palms and soles were massaged. Patient is instructed to spit out sputum 
into spit bowl placed on the convenient side of the patient. Prayogika Dhoomapana followed by Ushnajala Kavala is done.

\section{Research design}

a) Group CD

Administration Schedule - 7 Consecutive days. Formulation-PrasariniTaila

Dose $-4 \mathrm{ml}$ in each nostril.

b) Group AD

Administration Schedule - 13 Alternative days

Formulation-PrasariniTaila

Dose $-4 \mathrm{ml}$ in each nostril.

Follow up - Once in 15 days for 2 months.

Study Duration - 7 days

Assessment Criteria: Assessment of the condition was done based on the detailed proforma adopting standard method of scoring of subjective and objective parameters which was analyzed statistically.

Subjective Parameters

- Stiffness

- Neck pain

- Radiating pain

- Neck disability index

Objective Parameters

- Tenderness

- Range of movement of neck

\section{Statistical Test}

Obtained data were analyzed statistically with Paired and Unpaired t-test.

\section{Laboratory Investigations}

X-ray of cervical spine AP-lateral view.

\section{Observation \& Result}

\section{Observation}

A total of 40 patients suffering from Cervical Spondylosis fulfilling the inclusion criteria were taken for the study.

Observations were made before, during and after the treatment.

Number of patients registered for the study -40

Number of patients completed the study -40

Number of dropout -0
Incidence Observation: As per the prepared proforma, observations were made regarding the incidence of age, sex, occupation etc.

Age - $57.5 \%$ of patients were belonging to $20-30$ years of age group; $22.5 \%$ patients were from $41-50$ years of age group; $15 \%$ from $31-40$ years of age group; $7.5 \%$ were of $50-60$ years of age group.

Sex $-67.5 \%$ were females and $32.5 \%$ were males.

Occupation - Maximum number of patients were students $20 \%$ and $12.5 \%$ were office workers and others.

Bowel - 100\% patients were regular.

Exercise - 100\% were not doing any of the exercises.

Sleep - 75\% had sound sleep and 25\% had disturbed sleep.

Habits - 100\% were not having any of the habits.

Prakruthi - Majority of the patients belonged to Kaphavata prakruthi, 40\%, 32.5\% belonged to $\mathrm{Va}$ takapha prakruthi, $15 \%$ belonged to Kaphapitta prakruthi and $10 \%$ belonged to Vatapitta prakruthi

Samhanana - 100\% patient was of Madhyama Samhanana.

Satva - 100\% patient was of Madhyama Satva.

Agni -Majority patients were 65\% Mandagni and 35\% Teekshnagni.

Chronicity - Majority of the patients taken up for the study had the complaints which were ranging from 2 5 years, $35 \%$. $27.5 \%$ had 6 months - 1year, $22.5 \%$ had $1-6$ months, $10 \%$ had $1-30$ days and $5 \%$ had $6-10$ years.

\section{Results}

Effect on stiffness: Statistical analysis shows that the mean score which was 1.700 before the treatment is reduced to 0.500 after the treatment and after follow up it became 0.000 with $100 \%$ improvement and there is statistically highly significant $(\mathrm{P}<0.001)$.

Effect on neck pain: Statistical analysis shows that the mean score which was 1.300 before the treatment is reduced to 0.000 after the treatment and after follow up it became 0.000 with $100 \%$ improvement and there is statistically highly significant $(\mathrm{P}<0.001)$.

Effect on radiating pain: Statistical analysis shows that the mean score which was 2.900 before the treatment is reduced to 0.500 after the treatment and after 
follow up it became 0.000 with $100 \%$ improvement and there is statistically highly significant $(\mathrm{P}<0.001)$.

Effect on tenderness: Statistical analysis shows that the mean score which was 3.050 before the treatment is reduced to 0.000 after the treatment and after follow up it became 0.000 with $100 \%$ improvement and there is statistically highly significant $(\mathrm{P}<0.001)$.

Effect on flexion: Statistical analysis shows that the mean score which was 1.800 before the treatment is reduced to 0.500 after the treatment and after follow up it became 0.000 with $100 \%$ improvement and there is statistically highly significant $(\mathrm{P}<0.001)$.

Effect on extension: Statistical analysis shows that the mean score which was 2.100 before the treatment is reduced to 0.000 after the treatment and after follow up it became 0.000 with $100 \%$ improvement and there is statistically highly significant $(\mathrm{P}<0.001)$.

Effect on right lateral flexion: Statistical analysis shows that the mean score which was 1.250 before the treatment is reduced to 0.450 after the treatment and after follow up it became 0.000 with $100 \%$ improvement and there is statistically highly significant $(\mathrm{P}<0.001)$.

Effect on left lateral flexion: Statistical analysis shows that the mean score which was 1.350 before the treatment is reduced to 0.000 after the treatment and after follow up it became 0.000 with $100 \%$ improvement and there is statistically highly significant $(\mathrm{P}<0.001)$.

Effect on right rotation: Statistical analysis shows that the mean score which was 42.500 before the treatment is improved to 68.750 after the treatment and after follow up it became 75.500 with $77.6 \%$ improvement and there is statistically highly significant $(\mathrm{P}<0.001)$.

Effect on left rotation: Statistical analysis shows that the mean score which was 52.000 before the treatment is improved to 66.500 after the treatment and after follow up it became 77.000 with $48 \%$ improvement and there is statistically highly significant $(\mathrm{P}<0.001)$.

Result of Group CD: The percentage of improvement in Group CD on Stiffness is $100 \%$. Neck pain is $100 \%$, Radiating pain is $100 \%$, Tenderness is $100 \%$, Flexion is $33 \%$, Extension is $23 \%$, Right lateral flex- ion is $21.6 \%$, Left lateral flexion is $15.3 \%$, Right rotation is $25.8 \%$ and Left rotation is $31.3 \%$.

Result of Group AD: The percentage of improvement in Group $\mathrm{AD}$ on Stiffness is $100 \%$. Neck pain is $100 \%$, Radiating pain is $100 \%$, Tenderness is $100 \%$, Flexion is $48 \%$, Extension is $34 \%$, Right lateral flexion is $16.8 \%$, Left lateral flexion is $13.9 \%$, Right rotation is $13.2 \%$ and Left rotation is $17.6 \%$.

\section{Comparative result of Group CD and Group AD}

Comparative analysis of the overall effect of the treatments in both the groups was done statistically with unpaired $t$ test. The test shows that the treatment is statistically significant in Group $\mathrm{AD}$ when compared to Group CD.

\section{DISCUSSION}

Discussion on clinical study: In the present study, a total of 40 patients suffering from cervical spondylosis were randomly selected from OPD \& IPD of Alva's Ayurveda Medical College, irrespective of sex, occupation etc and the patients were categorized into two groups. Group CD and Group AD received Nasyakarma with Prasarini Taila for a duration of 7 days and follow up was done on 15 th day, $30^{\text {th }}$ day, $45^{\text {th }}$ day and $60^{\text {th }}$ day.

Total of 40 patients were registered for the study and 40 patients completed the study (20 in each group). The details are as follows.

a) Total patients registered in the study - 40

b) Patients who received Nasya with Prasarini Taila (Group CD) - 20

c) Patients who received Nasya with Prasarini Taila (Group AD) - 20

d) Completed -40

Discussion on observations: The discussion on observations related to the various aspects of 40 patients of Cervical Spondylosis are as follows:-

Age: Among 40 patients included for the study, maximum number of patients belonged to the age group of 20-30 and 41-50 years. As majority of the subjects enrolled were professionals and the age advances vitiation of Vata will be more, which is one of the main causes for Dhatukshaya. 
Sex: Majority of the patients enrolled for the study were $(67.5 \%)$ females. This may be due to over exertion of work as well as prolonged sitting posture.

Occupation: Maximum number of patients were students $(45 \%)$ and $(12.5 \%)$ were office workers and other workers. Improper posture and long-time study hours predisposed the students to strain of the neck. Continuous sitting in offices and neck exertions create undue pressure over cervical spine that may result in cervical spondylosis.

Prakruti: KaphaVata Prakruti was observed in maximum patients (40\%) followed by VataKapha Prakruti (32.5\%), KaphaPitta (15\%) and VataPitta $(10 \%)$. It suggests that KaphaVata and VataKapha Prakruti, due to predominance of Vata are more susceptible to degenerative diseases like Cervical Spondylosis.

Samhanana, Satva: The distribution of the patients shows that all the patients were having Madhyama Samhanana (100\%) and Madhyama Satva (100\%).

Nidra: The study shows that majority of patients had sound sleep.

Clinical features: Neck pain is a chief complaint of Cervical Spondylosis, associated with radiating pain, tenderness and stiffness which was observed in majority of the patients enrolled for the study. Range of movement is reduced in all 40 patients.

Chronicity: Majority of the patients taken up for the study had the complaints which were ranging from 25 yrs $35 \%$. $27.5 \%$ of the patient of this study had the chronicity of 6 months-1year. $22.5 \%$ were $1-6$ months. $10 \%$ were $1-30$ days and 5\% were $6-10$ yrs.

Discussion on result:

\section{Effect on stiffness}

After treatment: In this study the mean score of stiffness on 7th day was reduced from 1.700to 0.500 and 1.300 to 0.000 in Group CD and Group AD respectively. The percentage of relief was $100 \%$ and $100 \%$ which was statistically highly significant at 'P' value $<0.001$.

Follow up: On 15thday, $30^{\text {th }}$ day, $45^{\text {th }}$ day and $60^{\text {th }}$ day mean score of stiffness was reduced from 1.700 to 0.000 and 1.300 to 0.000 in Group CD and Group AD respectively. The percentage of relief was $100 \%$ and
$100 \%$ which was statistically significant at ' $\mathrm{P}$ ' value $<0.001$.

Comparison between the groups: When the values between the groups are compared, the mean difference score of stiffness in Group CD is 0.500 and in Group $\mathrm{AD}$ is 0.000 . The variation seen in these two groups are statistically significant.

\section{Effect on neck pain:}

After treatment: The mean score of neck pain on 7th day was reduced from 2.900 to 0.500 and 3.050 to 0.000 in Group CD and Group AD respectively. The percentage of relief was $82.7 \%$ and $100 \%$ in both groups, which was highly significant at ' $\mathrm{P}$ ' value $<0.001$.

Follow up: On 15 th day, $30^{\text {th }}$ day, $45^{\text {th }}$ day and $60^{\text {th }}$ day mean score of neck pain was reduced from 2.900 to 0.000 and 3.050 to 0.000 in Group CD and Group $\mathrm{AD}$ respectively. The percentage of relief was $100 \%$ and $100 \%$ which was statistically significant at ' $P$ ' value $<0.001$.

Comparison between the groups: When the values between the groups were compared, the mean difference score of neck pain in Group CD is 0.500 and in Group $\mathrm{AD}$ is 0.000 . The variation seen in these two groups are statistically significant.

\section{Effect on radiating pain:}

After treatment: The mean score of radiating pain on 7 th day was reduced from 1.800 to 0.500 and 2.100 to 0.000 in Group CD and Group AD respectively. The percentage of relief was $72 \%$ in Group CD and $100 \%$ in Group $\mathrm{AD}$ which was highly significant at ' $\mathrm{P}$ ' value $<0.001$.

Follow up: On 15 th day, $30^{\text {th }}$ day, $45^{\text {th }}$ day and $60^{\text {th }}$ day mean score of radiating pain was reduced from 1.800 to 0.000 and 2.100 to 0.000 in Group CD and Group AD respectively. The percentage of relief was $100 \%$ and $100 \%$ which was statistically significant at 'P' value $<0.001$.

Comparison between the groups: When the values between the groups were compared, the mean difference score of radiating pain in Group CD is 0.500 and in Group $\mathrm{AD}$ is $\mathrm{S} 0.000$. The variation seen in these two groups are statistically significant. 


\section{Effect on tenderness:}

After treatment: The mean score of tenderness on 7 th day was reduced from 1.250 to 0.450 and 1.350 to 0.000 in Group CD and Group AD respectively. The percentage of relief was 64\% in Group CD and 100\% in Group $\mathrm{AD}$ which was highly significant at ' $\mathrm{P}$ ' value $<0.001$.

Follow up: On 15 th day, $30^{\text {th }}$ day, $45^{\text {th }}$ day and $60^{\text {th }}$ day mean score of tenderness was reduced from 1.250 to 0.000 and 1.350 to 0.000 in Group CD and Group AD respectively. The percentage of relief was $100 \%$ and $100 \%$ which was statistically significant at ' $P$ ' value $<0.001$.

Comparison between the groups: When the values between the groups were compared, the mean difference score of tenderness in Group CD is 0.450 and in Group AD is 0.000 . The variation seen in these two groups are statistically significant.

\section{Effect on flexion:}

After treatment: The mean score of flexion on 7th day was improved from 42.500 to 60.500 and 52.000 to 66.500 in Group CD and Group AD respectively. The percentage of relief was $42.3 \%$ in Group CD and $27 \%$ in Group $\mathrm{AD}$ which was highly significant at ' $\mathrm{P}$ ' value $<0.001$.

Follow up: On $15^{\text {th }}$ to 45 thday, mean score of flexion was improved from 42.500 to 68.750 and 60 th day, 42.500 to 75.500 in Group CD respectively. On $15^{\text {th }}$ day mean score of flexion was improved from 52.000 to $73.000,30^{\text {th }}$ day, mean score was improved from 52.000 to 76.000 and 45 th to $60^{\text {th }}$ day, mean score was improved from 52.000 to 77.000 in Group AD. The percentage of relief was $42.3 \%, 61.7 \%$ and $77.6 \%$ in Group $\mathrm{CD}$ and $40 \%, 46 \%$ and $48 \%$ in Group $\mathrm{AD}$ which was statistically significant at ' $\mathrm{P}$ ' value $<0.001$.

Comparison between the groups: When the values between the groups were compared, the mean difference score of flexion in Group CD is 60.500 and in Group $\mathrm{AD}$ is 66.500 . The variation seen in these two groups are statistically significant.

\section{Effect on extension:}

After treatment: The mean score of extension on 7th day was improved from 46.500 to 60.500 in Group $\mathrm{CD}$ and 52.000 t0 66.500 in Group AD. The percent- age of relief was $30 \%$ and $27.8 \%$ in Group CD and Group AD which was highly significant at ' $\mathrm{P}$ ' value $<0.001$.

Follow up: $15^{\text {th }}$ day improved from 46.500 to 67.000 and $30^{\text {th }}$ to $60^{\text {th }}$ day 46.500 to 69.500 in Group CD and mean score of extension on $7^{\text {th }}$ day was improved from 52.000 to $66.500,15^{\text {th }}$ day from 52.000 to $68.000,30^{\text {th }}$ day from 52.000 to 69.500 and $45^{\text {th }}$ to $60^{\text {th }}$ day from 52.000 to 70.000 in Group AD respectively. The percentage of relief was $44 \%$ and $49.4 \%$ in Group $\mathrm{CD}$ and $30 \%, 33 \%$ and $34 \%$ in Group AD which was highly significant at ' $\mathrm{P}$ ' value $<0.001$

Comparison between the groups: When the values between the groups were compared, the mean difference score of extension in Group CD is 60.500 and in Group $\mathrm{AD}$ is 66.500 . The variation seen in these two groups are statistically significant.

\section{Effect on right lateral flexion:}

After treatment: The mean score of right lateral flexion on $7^{\text {th }}$ day was improved from 37.000to 43.500 and 38.500 to 45.000 in Group CD and Group AD respectively. The percentage of relief was $17.5 \%$ and $16.8 \%$ which was statistically highly significant at 'P' value $<0.001$.

Follow up: On $15^{\text {th }}$ day, $30^{\text {th }}$ day, $45^{\text {th }}$ day and $60^{\text {th }}$ day mean score of right lateral flexion was improved from 37.000 to 45.000 and 38.500 to 45.000 in Group CD and Group $\mathrm{AD}$ respectively. The percentage of relief was $21.6 \%$ and $16.8 \%$ which was highly significant at 'P' value $<0.001$

Comparison between the groups: When the values between the groups are compared, the mean difference score of right lateral flexion in Group CD is 43.500 and in Group $\mathrm{AD}$ is 45.000. The variation seen in these two groups are statistically significant.

\section{Effect on left lateral flexion:}

After treatment: The mean score of left lateral flexion on 7thday was improved from 39.000 to 43.250 and 39.500 to 45.000 in Group $\mathrm{CD}$ and Group $\mathrm{AD}$ respectively. The percentage of relief was $10.8 \%$ and $13.9 \%$ which was statistically highly significant at ' $\mathrm{P}$ ' value $<0.001$.

Follow up: On $15^{\text {th }}$ day, $30^{\text {th }}$ day, $45^{\text {th }}$ day and $60^{\text {th }}$ day mean score of left lateral flexion was improved from 
39.000 to 45.000 and 39.500 to 45.000 in Group CD and Group AD respectively. The percentage of relief was $15.3 \%$ and $13.9 \%$ which was highly significant at 'P' value $<0.001$

Comparison between the groups: When the values between the groups are compared,

the mean difference score of left lateral flexion in Group CD is 43.250 and in Group AD is 45.000 . The variation seen in these two groups are statistically significant.

\section{Effect on right rotation:}

After treatment: The mean score of right rotation on 7thday was improved from 71.500 to 82.000 and 79.500 to 89.000 in Group CD and Group AD respectively. The percentage of relief was $14.6 \%$ and $11.9 \%$ which was statistically highly significant at ' $\mathrm{P}$ ' value $<0.001$.

Follow up: On $15^{\text {th }}$ day, $30^{\text {th }}$ day, $45^{\text {th }}$ day and $60^{\text {th }}$ day mean score of right rotation was improved from 71.500 to 90.000 and 79.500 to 90.000 in Group CD and Group AD respectively. The percentage of relief was $14.6 \%$ and $11.9 \%$ which was highly significant at 'P' value $<0.001$

Comparison between the groups: When the values between the groups are compared, the mean difference score of right rotation in Group CD is 82.000 and in Group AD is 89.000 to 90.000 . The variation seen in these two groups are statistically significant.

\section{Effect on left rotation:}

After treatment: The mean score of left rotation on 7thday was improved from 68.500 to 81.500 and 76.500 to 88.000 in Group CD and Group AD respectively. The percentage of relief was $18.9 \%$ and $15 \%$ which was statistically highly significant at ' $\mathrm{P}$ ' value $<0.001$.

Follow up: On $15^{\text {th }}$ day, $30^{\text {th }}$ day, $45^{\text {th }}$ day and $60^{\text {th }}$ day mean score of left rotation was improved from 68.500 to 90.000 and 76.500 to 90.000 in Group CD and Group AD respectively. The percentage of relief was $31.3 \%$ and $17.6 \%$ which was highly significant at ' $P$ ' value $<0.001$.

Comparison between the groups: When the values between the groups are compared, the mean difference score of left rotation in Group CD is 81.500 and in
Group AD is 88.000. The variation seen in these two groups are statistically significant.

\section{Discussion on mode of action of drug}

Selected drug for the study ie, Prasarini Taila were prepared by the TailaPaka Vidhi. The ingredients of Prasarini Taila are Prasarini, Chitraka, Pippalimula, Madhuka, Vaca, Satapuspa, Devadaru, Rasna, Jatamamsi, Raktacandana, Bala, Gajapippali, Eranda, Sunthi, Tilataila, Kanjika, Ksheera and Mastu. These drugs possess properties such as Katu, Madhura rasa, Laghu, Snigdhaguna, Ushnavirya and Katuvipaka. Katu rasa improves circulations and clears the channels. Madhura rasa has Brimhana and Tarpana properties which acts on degeneration of bone. Laghu guna has Kaphahara property. Snigdha guna helps to alleviate aggravated Vata. Ushna Virya helps to alleviate Vata and Kapha Dosha. KatuVipaka subsides Kapha.

\section{Discussion on mode of action of Nasya}

Prasarini Taila administered through nostrils reaches the Shringataka Marma which is supplied to Nasa, Karna, Netra and Jihwa. After reaching Shringataka Marma spreads in the Murdha reaches the Netra, Srotra, Kanta, Siramukhas and it removes the morbid dosha present in Urdwajatru and expels out from Uthamanga. The action of drugs reaches greeva pradesha and reduces the symptoms of Cervical Spondylosis. Importance of the Purva Karma in Nasyakarma is to facilitate for drug absorption through nasal neurons and paranasal sinuses. Taila administered through nose enters into Shiras and morbid doshas draws out as the Ishika is taken out after removing the fibrous coating of Munja adhered to it.

\section{Effect on drug absorption and transportation}

Keeping the head in lowered position and retention of medicine in nasopharynx helps in providing enough time for local drug absorption. Any lipid soluble substance has greater possibility for passive absorption directly through the cells of lining membrane.

Sthanika Abhyanga and Swedana also enhances the drug absorption.

Neurological pathway of drug action

The stimulation of olfactory nerves causes stimulation in the cells of hypothalamus and amygdaloidal com- 
plex. So, the drugs administered through nasal route, stimulates the higher centers of brain which shows action on regulation of endocrine and nervous system functions.

\section{Vascular pathway}

Vascular path transportation is possible through the pooling of nasal venous blood to the facial vein, which naturally occurs. Inferior ophthalmic veins also pool into the facial vein. Both facial and ophthalmic veins have no venous valves in between. So, the blood may drain on either side. Such pooling of blood from nasal veins to venous sinuses of the brain, is more likely in the head lowered position due to gravity. Pooling of blood from paranasal sinuses also possible.

\section{Lymphatic pathway}

Drug transportation by lymphatic path can reach directly into the CSF. When provocation of dosha takes place in head due to irritating effect of administered drug resulting in increase of the blood circulation of brain. So accumulated morbid dosha are expelled out from small blood vessels and ultimately these morbid dosha are thrown out as nasal discharge, tear and salivation.

\section{Impact of Nasya on neuro vascular modulation}

The medicine given in Nasyakarma is getting pooled in cavernous sinus, which in turn reaches the vascular circulation of cervical region. The contents of the medicine are able to reach the CSF due to its lipid form and reaches the spinal cord and acts on the cervical nerves. Thus, the medicine acts in cervical region to cure cervical spondylosis. Hypothalamus, subthalamus and substantia Nigra are also influenced by Nasyakarma, in turn regulates the movements of the body and nervous system. Thus, motor functions and sensory functions might get better relief. Either the Veerya of Nasya or Nasya dravya is reaching the brain and acting on important centers controlling different neurological, endocrine and circulatory functions and thus showing systemic effect.

\section{CONCLUSION}

Cervical spondylosis as a whole cannot be as such compared to any single disease pathology in Ayurvedic parlance. But seems to have more resemblance to
Vishvachi. Nasya karma performed with Prasarini Taila, helps to pacify the Vataprakopa due to its Snehana and Brimhana properties and increases functional ability. The study showed significant results on $7^{\text {th }}$ day and even after follow-up study in the signs and symptoms of cervical spondylosis. On comparison between the groups, statistically significant result was observed in majority of criterias, which highlight the efficacy of the Prasarini Taila NasyaKarma in Cervical Spondylosis. Clinically, Group AD showed more effective results in all attributes, when compared to Group CD. The alternative hypothesis H1- There is significant effect of alternative days of Nasyakarma with Prasarini Taila in Vishvachi when compared to Consecutive days administration is accepted.

\section{REFERENCES}

1. Vagbhata, Ashtang Hrdaya with SarvangaSundara commentary of Arunadatta and Hemadri, edited by Bhishagacharya Hari sasthriparadakara Vaidhya, published by Chaukambha Orientalia, Varanasi, reprint edition 2010, Sutra Sthana 20:14 pp 258.

2. Susrutha, Susrutha Samhita with Nibandhasangraha commentary of Dalhanacharya and the Nyaya chandrikapanchika of Gayadas Acharya on nidanasthana edited Y.T. Acharya. Chaukambha Orientalia, varanasi, Uttarpradesh. reprint edition (2010), NidanaSthana 1:75pp268.

3. Agnivesa, Caraka Samhita with Ayurveda Dipika commentary of Chakrapani Dutta edited by Vaidya Yadavji Trikamji Acharya published by Chaukambha publications New Delhi, reprint edition (2014), Chikitsa Sthana 28:11,56-57pp619.

4. Agnivesa, Caraka Samhita with Ayurveda Dipika commentary of Chakrapani Dutta edited by Vaidya Yadavji Trikamji Acharya published by Chaukambha publications New Delhi, reprint edition (2014), Sutra Sthana 20:11pp113.

5. KV Krishnadas, Textbook of medicine volume 2 published by Jaypee brothers' medical publishers sixth edition 2017, section 17, chapter 210, pp 1451

6. Vagbhata, Ashtang Hrdaya with Sarvanga Sundara commentary of Arunadatat and Hemadri, edited by Bhishagacharya Hari sasthriparadakara Vaidhya, published by Chaukambha Orientalia Varanasi, reprint edition (2010), ChikitsaStana 21:1-3 pp722. 
7. Susrutha, Susrutha Samhita with Nibandha Sangraha Commentary of Dalhanacharya and the Nyaya chandrikapanchika of Gayadas Acharya on NidanaSthana edited Y.T. Acharya Chaukambha Orientalia, Varanasi, Uttarpradesh reprint edition (2010), Chikitsa Sthana 40:54-55 pp557.

8. Bhavaprakash, Sheemadbhishagbhooshana Bhavamishrapranitah, vidyotini- Namakaya bhasha Tikayasamvaatitah edited with Vidhyotinihindhi commentary by Bhishagratna Pandit Sri Bhrahma Sankar Mishra, Chaukambha Sanskrit bhavan, Varanasi $11^{\text {th }}$ edition (2010), chikitsasthana 24:32-42pp230

9. Susruta, Susrutha Samhitha with Nibandhasangraha commentary of Dalhanacharya and Nyayachandrika Panjika of Sri Gayadasacharya, edited by Vaidya Jadavji Trikamji Acharya, Chaukamba Sanskrit Sansthan, Reprint-2008, Chikitsa Sthana 40/21-29; Pp: 554-555

10. Bhavamisra: Bhavaprakasha translated by Pandit Sri Bhrahma Sankara Misra,11th edition, published by Chaukhambha Sanskrit Bhawan, Varanasi, Vol-1, Pu. Kh. 5/189; Pp: 882.

11. RigVeda Samhita, Published by Nityagnihotri Somayaji V. R. Laxmikanth Sharma Dwivedi, Kumbhakonam, Tamilnadu; 1979. 20/83/13; Pp: 757

12. The Atharvaveda, English Translation by Devi Chand M.A., Published by Munshiram Manoharlal Publishers Pvt Ltd, New Delhi; 1997. 10/2/32; Pp:434

13. The Atharvaveda, English Translation by Devi Chand M.A., Published by Munshiram Manoharlal Publishers Pvt Ltd, New Delhi; 1997. 9/8/1; Pp: 332

14. Bhagavad Gita - As it is, English Translation by A. C. Bhaktivedanta Swami Prabhupada, 19th print 2002, Published by The Bhaktivedanta Book Trust, Mumbai; 5/13; Pp 286

15. Agnivesa, Charakasamhitha with Ayurveda Deepika Commentary of Chakrapani edited by Acharya Yadavji Trikamji Published by Chaukamba Sanskrit Sansthan; Varanasi, Reprint Edition-2011. ShareeraSthana 8/19. Pp:343

16. Agnivesa, Charakasamhitha with Ayurveda Deepika Commentary of Chakrapani edited by Acharya Yadavji Trikamji Published by Chaukamba Sanskrit Sansthan; Varanasi, Reprint Edition-2011. Chikitsa Sthana 3/254255. Pp: 421

17. Agnivesa, Charakasamhitha with Ayurveda Deepika Commentry of Chakrapani edited by Acharya Yadavji Trikamji Published by Chaukamba Sanskrit Sansthan;
Varanasi, Reprint Edition-2011. Chikitsa Sthana 4/97111.Pp: 434

18. Agnivesa, Charakasamhitha with Ayurveda Deepika Commentry of Chakrapani edited by Acharya Yadavji Trikamji Published by Chaukamba Sanskrit Sansthan; Varanasi, Reprint Edition-2011. Chikitsa Sthana 7/4849. Pp: 452

19. Agnivesa, Charakasamhitha with Ayurveda Deepika Commentry of Chakrapani edited by Acharya YadavjiTrikamji Published by Chaukamba Sanskrit Sansthan; Varanasi, Reprint Edition-2011. ChikitsaSthana 8/34-35. Pp: 460

20. Agnivesa, Charakasamhitha with Ayurveda Deepika Commentry of Chakrapani edited by Acharya Yadavji Trikamji Published by Chaukamba Sanskrit Sansthan; Varanasi, Reprint Edition-2011. Chikitsa Sthana 9/ 35, 56-58,65-69,71,72; Pp: 471-473

21. Agnivesa, Charakasamhitha with Ayurveda Deepika Commentry of Chakrapani edited by Acharya Yadavji Trikamji Published by Chaukamba Sanskrit Sansthan; Varanasi, Reprint Edition-2011. Chikitsa Sthana 10/4045. Pp: 477

22. Agnivesa, Charakasamhitha with Ayurveda Deepika Commentry of Chakrapani edited by Acharya YadavjiTrikamji Published by Chaukamba Sanskrit Sansthan; Varanasi, Reprint Edition-2011. Chikitsa Sthana 12/17. Pp:484

\section{Source of Support: Nil \\ Conflict of Interest: None Declared}

How to cite this URL: Krishnapriya A. S \& Praveen B. S: A Comparative Clinical Study To Evaluate Different Schedules Of Marsha Nasya With Prasarini Taila In Cervical Spondylosis. International Ayurvedic Medical Journal \{online\} 2020 \{cited August, 2020\} Available from: http://www.iamj.in/posts/images/upload/4107_4115.pdf 